Огляди літератури, оригінальні дослідження, погляд на проблему

удК 616.721-002.77-06:[616.127+616.24]-07/-08

DOI

\title{
ОЦІНКА ДЕПРЕСИВНИХ РОЗЛАДІВ У ХВОРИХ З АНКІЛОЗИВНИМ СПОНДИЛОАРТРИТОМ
}

\author{
ДВНЗ «Тернопільський державний медичний університет імені І. Я. Горбачевського МОз України»
}

РЕЗЮМЕ. Для визначення глибини депресивних змін обстежено 70 хворих на анкілозивний спондилоартрит (АТ) з використанням тесту Бека та шкали Тейлора. Встановлено, що найвищий рівень депресивних розладів зустрічається за умов вперше встановленого діагнозу анкілозивного спондилоартриту. Надалі при адекватному лікуванні вдається домогтися значного покращення психоемоційного стану на 1-10 році захворювання. Проте при поступовому прогресуванні захворювання за умов незворотних змін якість життя значно погіршується, що проявляється значним погіршанням в психоемоційній сфері і потребує медикаментозної корекції.

КЛЮчОВІ СЛОВА: анкілозивний спондилоартрит, депресія.

Вступ. Однією із проблем сучасної клінічної медицини $\epsilon$ своєчасна діагностика депресивних розладів та надання спеціалізованої допомоги в цьому напрямку. За даними Всесвітньої організації охорони здоров'я, депресивні розлади займають провідне місце серед 10 основних хвороб, які призводять до інвалідизації населення і набули у світі такої популярності, що вже з початку 2010 р. ВООЗ прирівняла її до епідемії, що поширилася на все людство [1]. За даними МОЗ України, у структурі захворюваності на психічну патологію понад 70 \% становлять психічні розлади непсихотичного рівня, серед яких переважають депресії [2].

Депресивні стани характеризуються трьома основними симптомами (так званою депресивною тріадою): зниженим настроєм, уповільненням мислення і руховою загальмованістю. Ці стани нерідко супроводжуються сльозливістю, дратівливістю, сварливістю, образливістю. Розумова діяльність при них сповільнена, збіднена, втрачений образний компонент мислення, у свідомості переважають мимовільні обтяжливі за своїм змістом думки, в яких минуле і сьогодення постають тільки як низка невдач і помилок, а майбутнє здається безцільним. Особливо інтенсивні симптоми депресії (і у легких, і у виражених випадках) у ранкові години, а в другій половині дня або увечері стан хворих може поліпшуватися. Це відрізняє депресію від астенічних станів, при яких самопочуття завжди погіршується до вечора. Разом з описаними типовими варіантами існує ряд атипових депресивних синдромів: дисфорична, ажитована депресія та іпохондрична депресія.

За даними Американського національного дослідження коморбідності, депресія $\epsilon$ найпоширенішим психічним розладом протягом життя: для чоловіків цей показник становить $13 \%$, для жінок - $22 \%$ [1].

Депресія $\epsilon$ незалежним фактором ризику розвитку серцево-судинних захворювань, а також погіршує перебіг уже наявної кардіологічної патології: ішемічної хвороби серця, хронічної серцевої недостатності, перенесеного інсульту, артеріальної гіпертензії [3-6].

Визначено три основних психобіологічних механізми, через які депресія впливає на серцевосудинну систему $[7,8]$ :

- порушення стресової відповіді ендокринної системи;

- гіперрегуляція автономної нервової системи;

- порушення в імунній системі з дизрегуляцією вивільнення білків гострої фази і прозапальних цитокінів.

Порушення регуляції гіпоталамо-гіпофізарнонаднирковозалозної системи призводить до гіпертензії, ожиріння, порушення толерантності до глюкози і гіперхолестеринемії [8]. При депресії відбувається порушення серотонінергічних i адренергічних шляхів передачі сигналів, накопичення метаболітів (таких як гомоцистеїн, фактор активації тромбоцитів і ряду інших) $[9,6]$. Серотонін має різні серцево-судинні ефекти, включаючи індукцію аритмії і вазоконстрикцію. Цій гіпотезі відповідають результати дослідження, які показали, що депресивний стан пов'язаний з дисфункцією ендотелію коронарних судин у пацієнтів без верифікованої IXC [4]. Тривала дія серотоніну призводить до проліферативних процесів в ендотелії і потовщення серцевих клапанів $[7,10]$.

Роботи, в яких вивчали взаємозв'язок між депресією і ризиком серцево-судинних захворювань, з'явилися в середині 90 років. У 1996 р. M. Fava та ін., обстеживши 138 амбулаторних пацієнтів з депресією в умовах первинної допомоги, висунули гіпотезу, що особи із депресією схильні до підвищеного ризику ускладнень ішемічної хвороби серця (IXC). Подальші дослідження підтвердили, що депресія в 1,52 раза підвищує ризик розвитку інфаркту міокарда [15]. 
Огляди літератури, оригінальні дослідження, погляд на проблему

Результати найбільшого міжнародного дослідження INTERHEART показали, що депресія і тривога, поряд з іншими психосоціальними факторами, входять у число 9 найважливіших факторів ризику, що визначають захворюваність і смертність від інфаркту міокарда у всьому світі, незалежно від статі, регіону проживання та етнічної належності людей [11].

Анкілозивний спондилоартрит як захворювання, в клініці якого чітко домінує інтенсивний больовий синдром, що характеризується постійним болем і загальною скутістю, не може не впливати на психоемоційний стан.

Доведено, що у хворих на АС $\epsilon$ підвищений ризик серцево-легеневої патології, тому постійна депресія може тільки погіршити прогноз у цих пацієнтів.

Мета роботи - проаналізувати частоту і глибину депресивних розладів у хворих на АС з різною тривалістю захворювання.

Матеріал і методи дослідження. Обстежено 70 хворих з верифікованим діагнозом АС, у яких проводили анкетування на наявність депресії $\mathrm{i}$ визначення рівня тривоги з використанням тесту Бека та шкали Тейлора.

Шкала депресії Бека (Beck Depression Inventory) розроблена на основі клінічних спостережень, які дозволяють виявити обмежений набір найбільш релевантних і значних симптомів депресії та найчастіших скарг пацієнтів, запропонована А. Т. Беком у 1961 р. Даний опитувальник включає 21 категорію симптомів та скарг. Кожна категорія складається з 4-5 тверджень, які відповідають найспецифічнішим проявам/симпто- мам депресії. Ці твердження побудовані по мірі збільшення внеску симптомів у загальну тяжкість депресії. Відповідно до ступеня вираження симптому кожному пункту присвоєні значення від 0 (симптом відсутній або виражений мінімально) до 3 (максимальний прояв симптому). Деякі категорії включають альтернативні твердження, що мають еквівалентну питому вагу.

Показник за кожною категорією розраховують наступним чином: кожен із пунктів шкали оцінюють від 0 до 3 балів відповідно до зростання тяжкості проявів/симптомів. Сумарний бал становить від 0 до 62 і знижується по мірі покращення стану пацієнта.

Незважаючи на те, що твердження $\epsilon$ дуже прямими і дозволяють досліджуваному приховувати свій справжній стан, використання анкети Бека в клінічній практиці показало її високу ефективність у скринінгу та попередньому обстеженні.

Результати й обговорення. Серед усіх обстежених пацієнтів 11,4 \% (8 хворих) були з вперше встановленим діагнозом, 14,2 \% (10 хворих) 3 тривалістю захворювання до 5 років, 22,9\% (16 хворих) - від 5 до 10 років, 38,6 \% (27 хворих) від 10 до 20 років, 12,9 \% (9 хворих) - понад 20 років відповідно.

У всіх пацієнтів, які брали участь у дослідженні були виявлені депресія та підвищений рівень тривоги, зокрема у 3 хворих (4\%) - субдепресія (легка форма), у 42 хворих (60\%) - помірна депресія, у 23 хворих (33\%) - виражена депресія (середнього ступеня тяжкості) і у 2 хворих (3\%) - тяжкий депресивний стан (рис. 1, табл. 1).

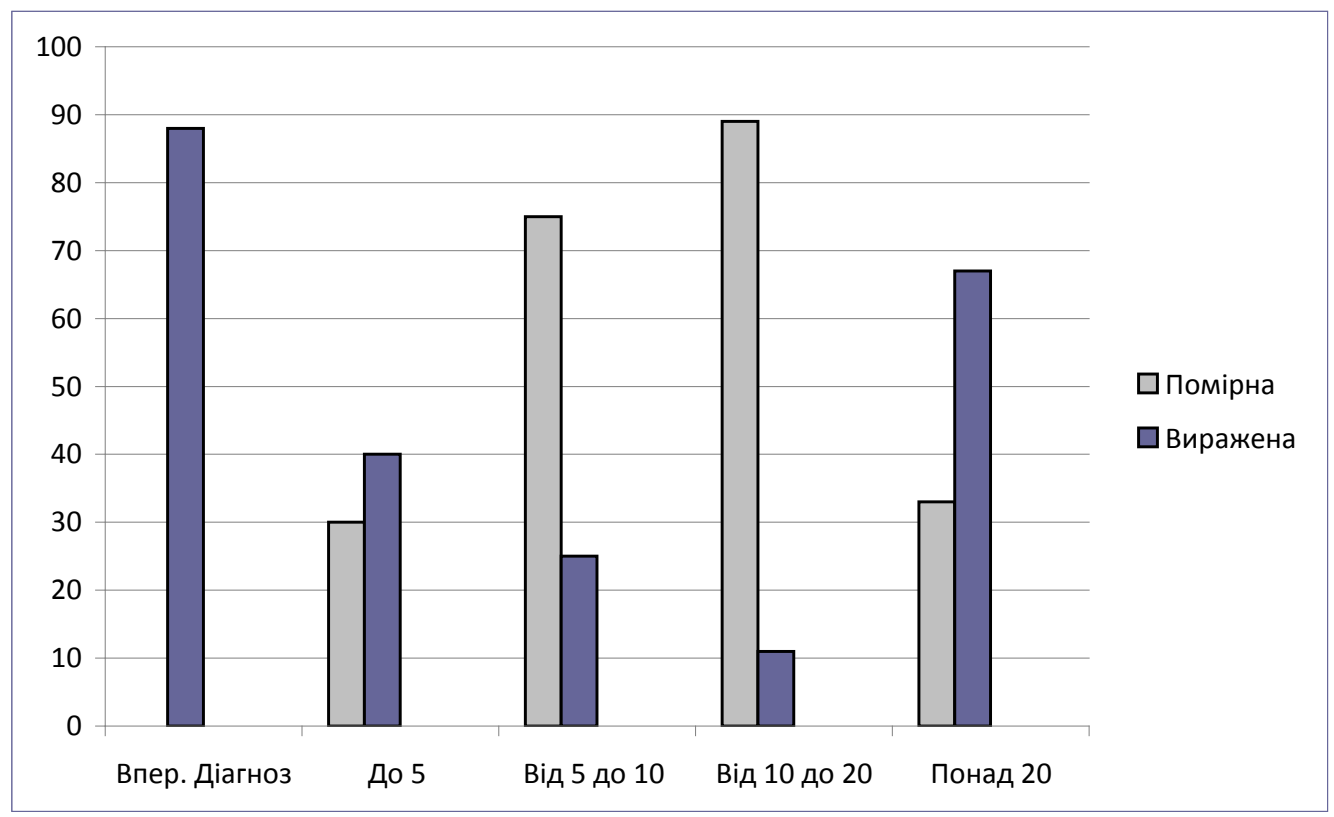

Рис. 1. Динаміка прояву депресій згідно вікових груп у обстежуваних пацієнтів. 
Огляди літератури, оригінальні дослідження, погляд на проблему

Таблиця 1. Співідношення депресивних порушень та тривалості захворювання

\begin{tabular}{|l|c|c|c|c|c|}
\hline \multirow{2}{*}{ Тип депресії } & \multicolumn{5}{|c|}{ Тривалість захворювання, років } \\
\cline { 2 - 6 } & вперше встановл. & до 5 & від 5 до 10 & від 10 до 20 & понад 20 \\
\hline Легка & - & $3(30 \%)$ & - & - & - \\
\hline Помірна & - & $3(30 \%)$ & $12(75 \%)$ & $24(89 \%)$ & $3(33 \%)$ \\
\hline Виражена & $7(88 \%)$ & $4(40 \%)$ & $4(25 \%)$ & $3(11 \%)$ & $5(56 \%)$ \\
\hline Тяжка & $1(12 \%)$ & & - & - & $1(11 \%)$ \\
\hline
\end{tabular}

Аналіз залежності рівня тривоги, депресії та тривалості недуги дозволив констатувати, що у пацієнтів із вперше встановленим діагнозом АC наявні достовірні рівні депресивних розладів, які відповідають депресії середнього і тяжкого ступенів, на відміну від пацієнтів із тривалим анамнезом недуги.

Пацієнти з тривалістю АС 5-10 років мали помірні депресивні розлади без формування тяжких депресивних станів. За умов 20-річного і більше стажу захворювання особи даної когорти мали депресію середнього ступеня тяжкості.

\section{ЛІТЕРАТУРА}

1. http://www.who.int/mediacentre/factsheets/en/

2. Наказ Міністерства охорони здоров'я України від 25 грудня 2014 р. № 1003.

3. Depression increasesthe risk of hypertension incidence: a meta-analysis of prospective cohort studies / L. Meng, D. Chen, Y. Yang [et al.] // J. Hypertens. - 2012. № 30 (5). - P. 842-851.

4. Coronaryendothelialdysfunctionassociated with a depressive mood in patients with atypicalangina but angiographically normal coronary artery / J. H. Kim, J. W. Kim, Y. H. Ko [et al.] // Int. J. Cardiol. - 2010. - № 143 (2). P. 154-157.

5. Yusuf S., Hawken S., Ounpu S., et al. on behalf of the INTERHEART Study Investigators. Effect of potentially modifiable risk factors associated with myocardial infarction in 52 countries (the INTERHEART Study): case-control study.www.thelancet.com. / S. Yusuf, S. Hawken, S. Ounpu, [et al.] Published online September 2004; 3.

6. Platelet functionin patients with major depression / R. C. Ziegelstein, K. Parakh, A. Sakhuja, U. Bhat // Int. Med. J. - 2008. - № 39 (1). - P. 38-43.

7. Depression.An underestimated risk for the development and progressionof coronary heart disease / K. H. Ladwig, R. T. Emeny, S. Hafner, M. E. Lacruz // Bundesgesundheitsblatt Gesundheitsforschung Gesundheitsschutz. - 2011. - № 54 (1). - P. 59-65.

8. Ford D. I. Depression and Creactive protein in US adults) Third National Health and Nutrition Examination Survey / D. I. Ford, T. P. Erlinger // Arch. Intern. Med. 2004. - № 164 (9). - 1010 p.
Висновок. Можна припустити, що найвищий рівень депресивних розладів виявляється за умов вперше встановленого діагнозу. Але з часом хворі навчаються жити з цим захворюванням, отримують адекватне лікування, що приводить до значного покращення психоемоційного стану на 1-10 році захворювання. Надалі ж, при поступовому прогресуванні захворювання, за умов незворотних змін якість життя значно погіршується, що проявляється значним погіршенням у психоемоційній сфері і потребує медикаментозної корекції.

9. Plante G. E. Depression and cardiovascular disease: a reciprocalrelationship / G. E. Plante // Metabolism. 2005. № 54 (5 Suppl. 1). - P. 45-48.

10. Endothelial biomarkers in depressed patients treated with the selective serotonin reuptake inhibitor sertraline after acute coronary events: the Sertraline AntiDepressant Heart Attack Randomized Trial (SADHART) Platelet Substudy / V. L. Serebryan, A. H. Glassman, A. I. Malinin [et al.] // Circulation. - 2003. - № 108 (8). - P. 939-944.

11. Chronic diseasesand risk for depression in old age: a meta-analysis of publishedliterature / C. Q. Huang, B. R. Dong, Z. C. Lu [et al.] // Ageing. Res. Rev. - 2010. № 9 (2). - P. 131-141.

12. Impact of depression syndrome in the management of cardiovascularrisk factors in primary prevention: State of the art / M. Colotto, G. Rubini, C. Savoriti [et al.] // Clin. Ter. - 2010. - № 161 (3). - P. 105-110.

13. Depression and the risk for cardiovascular diseases: systematic review and meta analysis / Van K. der Kooy, H. van Hout, H. Marwijk [et al.] // Int. J. Geriatr. Psychiatry. - 2007. - № 22 (7). - P. 613-626.

14. Voinov B. Depression and chronicdiseases: it is time for a synergistic mental health and primarycare approach / B. Voinov, W. D. Richie, R. K. Bailey // Prim. Care Companion CNS Disord. - 2013. - Vol. 15 (2).

URL: http://www.ncbi.nlm.nih.gov/pmc/articles/ PMC3733529/(available: 28.05.2014).

15. Корсакова Н. К., Экспресс-методика оценки когнитивных функций при нормальном старении / Н. К. Корсакова, Е. Ю. Балашова, И. Ф. Рощина // Журнал неврология и психиатрия. - 2009. - № 2. - Р. 44-50. 


\section{Horbachevsky Ternopil State Medical University}

SUMMARY. It was found that people with first diagnose of ankylosing spondylitis have the highest level of depressive disorders. Subsequent adequate treatment can achieve significant improvement in emotional state for 1-10 years of illness. However, with the gradual progression of the disease, irreversible changes in conditions significantly worsen the quality of life, which manifested with significant deterioration in the psycho-emotional sphere and in need of medical correction.

KEY WORDS: ankylosing spondylitis, depression. 